\title{
第一原理分子動方学法とその $\mathrm{S}$ i (001) 清浄表面。吸着面への応用
}

\author{
森 川良 忠・井上 耕一郎* - 寺 倉 清 之 \\ 東京大学物性研究所 ⿶106 東京都港区六本木 7-22-1 \\ * 九州大学教養部 5810 福岡市中央区六本松 4-2-1
}

(1992 年 9 月 8 日受理)

\begin{abstract}
First-Principles-Molecular-Dynamics Method and Its Application to the Studies of Clean and Alkali-Metal Adsorbed Si(001) Surfaces

\author{
Yoshitada Morikawa, Kouichirou Inoue* and Kiyoyuki Terakura \\ Institute for Solid State Physics, University of Tokyo, Roppongi, Minato, Tokyo 106 \\ * College of General Education, Kyushu University, Ropponmatsu, Fukuoka 810
}

(Received September 8, 1992)

\begin{abstract}
固体表面では原子配列の自由度が大きいため, 研究の基礎となる構造さえ求めるのが困難である場合が多 い。第一原理分子動力学法の発展によって, 固体表面のように自由度が大きい系の構造や電子状態を第一原 理から求めることが可能になった。乙の方法で得た結果は実験と良い精度で対応させることができ，さまざ まな実験結果を解釈する際の有用な情報を提供する。第一原理分子動力学法の威力が発揮された例として, 最近われわれのグループで行った $\mathrm{Si}(001)$ 清浄表面およびアルカリ金属吸着表面の研究について紹介する。 清浄表面については，二つのバックリングの自由度をあつ非対称ダイマーをイジングスピンと見なして，ス ピン間の有効相互作用の大きさを第一原理分子動力学法を用いて求め, 有限温度でのスピン配列のモンテカ ルロシミュレーションを行った。アルカリ金属吸着表面については, 吸着エネルギー, バンド構造, STM 像などについて解析を行った。
\end{abstract}

\section{1. 序}

1985 年に Car と Parrinello ${ }^{1,2)}$ が提案した第一原理分 子動力学法は, 自由度の大きい系の安定構造および電子 状態を第一原理計算によって求めるてとを可能にした。 本稿ではこの第一原理分子動力学法の基本原理とその 固体表面への応用, おょび今後の課題について解説を 行う。

\section{2. 第一原理分子動力学法}

固体の第一原理計算に最む広く用いられている近似法 は密度汎関数理論における局所密度近似である ${ }^{3,4)}$ 。一 電子波動関数 $\left\{\phi_{i}(\boldsymbol{r})\right\}$ 之原子座標 $\left\{\boldsymbol{R}_{\mu}\right\} \quad$ の汎関数であ る系の全エネルギー $E\left[\left\{\phi_{i}(\boldsymbol{r})\right\},\left\{\boldsymbol{R}_{\mu}\right\}\right] に, \phi_{i}(\boldsymbol{r})$ そつい ての変分原理を適用して Kohn-Sham 方程式

$$
H \psi_{i}(\boldsymbol{r})=\varepsilon_{i} \psi_{i}(\boldsymbol{r})
$$

ただし，

$$
H=\left(-\frac{1}{2} \nabla^{2}+\int \frac{\rho\left(\boldsymbol{r}^{\prime}\right)}{\left|\boldsymbol{r}-\boldsymbol{r}^{\prime}\right|} d^{3} r^{\prime}+\mu_{x}[\rho(\boldsymbol{r})]\right),
$$

が導かれる。(1)式で $\rho(\boldsymbol{r})$ は一電子密度， $\mu_{x}$ は交換 相関ポテンシャルである。通常は波動関数を適当な基底 関数 $\phi_{n}$ で展開し,

$$
\phi_{i}(\boldsymbol{r})=\sum_{n} c_{i}^{n} \phi_{n}(\boldsymbol{r}),
$$

行列

$$
H_{m n}=\int \phi_{m}^{*}(\boldsymbol{r}) H \phi_{n}(\boldsymbol{r}) d^{3} r,
$$

を対角化し，固有值および固有ベクトルを求める。波動 関数を展開する基底関数の数を $N$ とすると, ハミルトニ アンは $N \times N$ の行列になり, 対角化に要する演算の数 は $N^{3}$ 程度になる。乙のために，系の大きさが大きくな

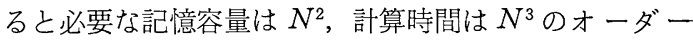


で增え，計算の遂行が急激に困難になる。さらに安定構 造を求めるには原子に働く力に従って構造を少しずつ動 かしては自己無撞着計算を行わなければならず，膨大な 計算時間が必要である。この困難は Car-Parrinello 法 の導入により大幅に軽減された。Car-Parrinello 法で は, 電子系の自由度 $\left\{\psi_{i}(\boldsymbol{r})\right\}$, および原子座標の自由度 $\left\{\boldsymbol{R}_{\mu}\right\}$ は位相空間中を仮想的に運動すると考える。その 運動の仮想的な時間を $t$ とし, ラグランジアンは

$$
\begin{aligned}
L= & \sum_{i} m \int\left|\frac{d}{d t} \phi_{i}(\boldsymbol{r} ; t)\right|^{2} d^{3} r+\sum_{\mu} \frac{1}{2} M_{\mu}\left|\frac{d}{d t} \boldsymbol{R}_{\mu}(t)\right|^{2} \\
& -E\left[\left\{\psi_{i}(\boldsymbol{r} ; t)\right\},\left\{\boldsymbol{R}_{\mu}(t)\right\}\right],
\end{aligned}
$$

とおく。乙こで $M_{\mu}$ はイオンの質量であり， $m$ は波動関 数の自由度に対する仮想的な質量であり実際には収束性 を調節するパラメーターの役割をする。 $\left\{\psi_{i}(\boldsymbol{r} ; t)\right\}$ およ び $\left\{\boldsymbol{R}_{\mu}(t)\right\}$ は Euler-Lagrange 方程式

$$
\begin{aligned}
& m \frac{d^{2}}{d t^{2}} \psi_{i}(\boldsymbol{r} ; t)=-H \psi_{i}(\boldsymbol{r} ; t)+\sum_{j} \lambda_{i j} \psi_{j}(\boldsymbol{r} ; t), \\
& M_{\mu} \frac{d^{2}}{d t^{2}} \boldsymbol{R}_{\mu}(t)=-\nabla_{\mu} E\left[\left\{\phi_{i}(\boldsymbol{r} ; t)\right\},\left\{\boldsymbol{R}_{\mu}(t)\right\}\right],
\end{aligned}
$$

に従って運動する。とてで（5)式の第二項は波動関数の 規格直交条件仁起因する項であり， $\lambda_{i j}$ はラグランジュ 未定乗数である。系の運動エネルギーを徐々に減少させ ていけば，系はポテンシャルE の極小の状態に落ち着 くであろうと考えられる。ポテンシャルの底に落ち着い たとき，すなわち( 5 )式の左辺が零になったとき, 行列 入が対角化されるようにユニタリ一変換すると, 方程式 (5)は Kohn-Sham 方程式 (1) 亿一致することがわか る。さらに，(5)式の右辺が常に小さくなるようにでき れば，(6)式で決まるイオンの運動は断熱ポテンシャル 面上の運動とみなすととができる。方程式 ( 5 ) は対角化 法に比べてつぎの点で優れている。

（1）方程式 (5)の右辺は行列とべクトルの積である ので, 必要な演算の数は $N^{2}$ となる。求めたい 固有状態の数を $M$ とすると, すべての固有状 態についての加速度を求めるには $M N^{2}$ の演算 が必要となるが, 通常, 基底の数 $N$ は求める 固有状態の数 $M$ よりあはるかに多いので対角 化法で必要な $N^{3}$ の演算よりあ少ない演算です む。さらに, 平面波を基底に選ぶと高速フーリ 工変換が利用でき, 演算回数は $M N \ln N$ まで 減らすととができる。

（2）ハミルトニアンの行列要素をすべて収容する必 要はなく, 記憶容量は少なくてすむ。

（3）ハミルトニアンの対角化，ハミルトニアンと波 動関数の自己無撞着化, および原子位置の最適 化の三つのステップが同時進行できるので, 今
まで困難であった構造最適化や第一原理計算に よる分子動力学が容易になる。

てれらの利点により, 従来可能であったよりあ大規模 な系を取り扱うことができ, しかむその最適化構造む求 めることができるようになった。

\section{3. $\mathrm{Si}(001)$ 清浄表面}

$\mathrm{Si}(001)$ 清浄表面においては，表面原子がダイマー列 を形成するてとが知られている。ダイマー列の存在は， 室温における STM の観測 ${ }^{5}$ によってあ確認されてい る。室温の STM 像の多くの領域ではダイマーは対称 ダイマーに見えるが, 電子状態計算 ${ }^{6}$ によると, ダイ マーが対称であるとすると，表面準位が金属的になり， 角度分解紫外光電子分光の測定 ${ }^{7}$ で半導体的な表面準位 が観測されるととと矛盾する。乙のととからダイマーが 傾いて非対称な構造になることが提案された ${ }^{8)}$ 。電子状 態計算によると，非対称なダイマーは対称ダイマーより あ安定で, 半導体的な表面準位を与える。一方, 村田 ${ }^{9}$ らのての表面での低速電子回折の測定結果によると, $200 \mathrm{~K}$ 以下の低温では $c(4 \times 2)$ パターンが観測されてい る。温度を上げていくと, $1 / 4$ 次スポットの強度は急激 に弱くなり, 整数次, 半整数次スポットのみが残る。て のような低速電子回折の構造の温度変化を説明するモデ ルとして，つぎのようなすのが考えられている。低温で は非対称ダイマーが, ダイマー列の方向にあダイマー列 に垂直な方向にも交互に反対向きに傾いて並んで $c(4 \times$ 2) 構造になり, 温度を上げていくと, ダイマーの配向が 無秩序な相に転移するてとによって，1/4 次スポットの 強度は急激に弱くなって広がり, スポットは整数次と半 整数次のみが残るというすのである。このモデルでは， 室温の STM 像でダイマーが対称に見えるのは, 無秩序 相に扔いては, ダイマーの反転運動が頻繁に起こってお り, その時間平均が STM で観測されるためであると 説明されている。最近の STM の観測の報告 ${ }^{10}$ による と，室温ではほとんど対称に見えるダイマーが $200 \mathrm{~K}$ 以下の低温になると非対称ダイマーになり，ダイマー列 方向に沿って交互に配向を変えてならんで, 多くの領域 で $c(4 \times 2)$ の配列になるととが確認されている。われわ れは，実際にてのようなモデルに従い低速電子回折で見 出された相転移の様子を第一原理分子動力学法とイジン グモデルを用いたモンテカルロシミュレーションを使っ て再現することを試みた。

まず第一原理分子動力学法を使って, 図 1 亿示すよう な $(2 \times 1)$ 構造, $(4 \times 1)$ 構造, $p(2 \times 2)$ 構造, $c(4 \times 2)$ 構造の四つの構造の最適化を行い，全エネルギーを計算 した。これらの四つの構造の全エネルギーの差からダィ 


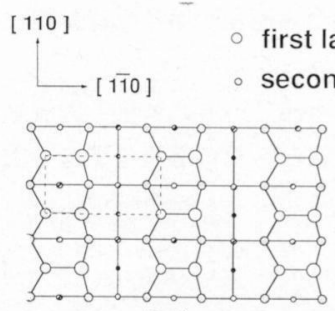

(2x1)

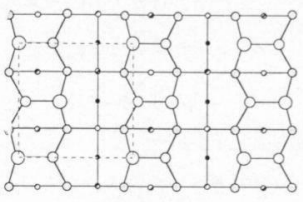

$\mathrm{p}(2 \times 2)$
- third layer Si

- fourth layer Si

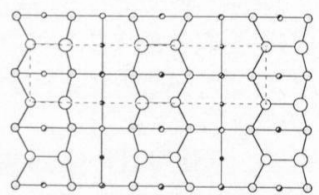

(4x1)

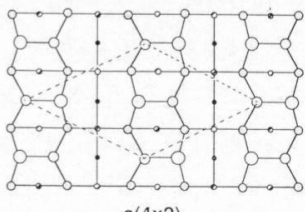

$c(4 \times 2)$
図 1 計算に用いられた四つの構造を真上から見た図 点線は各構造の基本単位格子表わす

表 $1 \quad(2 \times 1)$ 構造とのエネルギー差

\begin{tabular}{rc}
\hline & $E-E(2 \times 1)(\mathrm{meV})$ \\
\hline$(2 \times 1)$ & 0 \\
$(4 \times 1)$ & 27.5 \\
$p(2 \times 2)$ & -89.4 \\
$c(4 \times 2)$ & -90.6
\end{tabular}

マー間の有効相互作用を導きだした。四つの構造の $(2 \times 1)$ 構造を基準としたエネルギー差を表 1 亿示す。 四つの構造のうち, 最むエネルギーが低いのは $c(4 \times 2)$ 構造であった。この結果は低速電子回折の測定結果と一 致している。しかし, $c(4 \times 2)$ 構造と $p(2 \times 2)$ 構造との エネルギー差は，約 $1 \mathrm{meV}$ であった。このエネルギー 差の值は，計算法の精度の限界に近い。われわれの計算 では, 構造間のエネルギー差がどのくらいのカットオフ エネルギー, $k$ 点数で収束するかを四つの構造での計算 の前に調べ，十分と思われる值を使って計算を行った。 $c(4 \times 2)$ 構造と $p(2 \times 2)$ 構造の間のエネルギー差につ いては, さらに $k$ 点数を増やした計算を行ったが, やは り $c(4 \times 2)$ 構造のほうが約 $1 \mathrm{meV}$ 低いという結果に なった。ゆえに，この計算法の範囲内でこれ以上精度を 上げた計算を行っても $c(4 \times 2)$ 構造と $p(2 \times 2)$ 構造の 間のエネルギー差に，大きな変化は期待できないと思わ れる。また, $p(2 \times 2)$ 構造, $c(4 \times 2)$ 構造之 $(2 \times 1)$ 構 造, $(4 \times 1)$ 構造とのエネルギーの差は $p(2 \times 2)$ 構造と $c(4 \times 2)$ 構造のエネルギー差に比べてかなり大きい。 このととから，ダィマー列方向にそってダィマーが交互 に反対向きに並ぶことによるエネルギーの得が大きいこ とがわかる。 $c(4 \times 2)$ 構造の表面準位は半導体的であっ た。図 2 に計算された $c(4 \times 2)$ のエネルギーバンドと 遠田ら ${ }^{11)}$ にって測定された $c(4 \times 2)$ 構造の表面準位

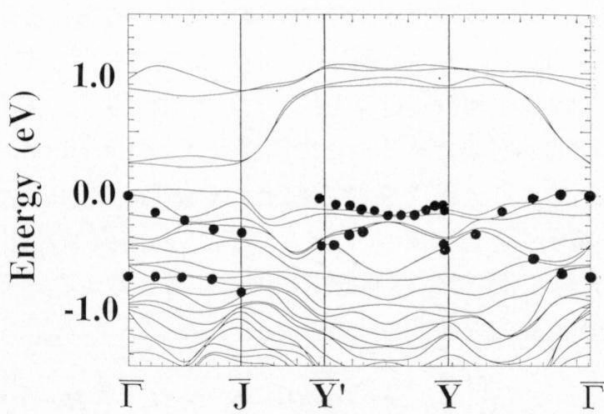

図 2 計算された $c(4 \times 2)$ 構造のエネルギーバンド (実線) と遠田ら ${ }^{11}$ による角度分解紫外光電子分光 の実験で観測された表面準位（黒丸）

の分散との比較を示す。計算結果は, 測定結果と比較的 よく一致している。また, 今回計算されたバンドは, 過 去に計算された $c(4 \times 2)$ のバンド12)ともだいたい合っ ている。

つぎに, この表面の秩序無秩序転移のシミュレーショ ンを行う。ダイマーは 2 通りの向きをとることから， $(i, j)$ サイトのダイマーを $S_{i, j}= \pm 1$ のイジングスピン で置き換えた。四つの構造に対応するスピン配列を図 3 に示してある。スピンの運動はつぎのような有効ハミル トニアン

$$
\begin{aligned}
H= & -V \sum_{i, j} S_{i, j} S_{i, j+1}-H \sum_{i, j} S_{i, j} S_{i+1, j} \\
& -D \sum_{i, j}\left(S_{i, j} S_{i+1, j-1}+S_{i, j} S_{i+1, j+1}\right),
\end{aligned}
$$

で記述した。 $V, H ， D$ は図 3 に示してあるスピン間相 互作用である。 $V, H, D$ の值は, 第一原理分子動力学

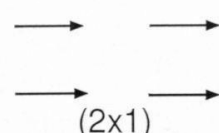

$(2 \times 1)$

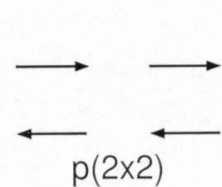

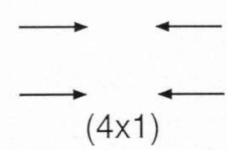

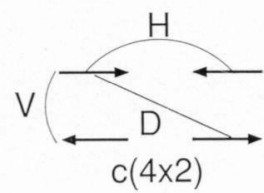

図 3 計算された四つの構造に対応するイジングス ピンの配置。 $V, H ， D$ はそれぞれ第 1 近接，第 2 近接, 第 3 近接のダイマー間の相互作用

表 2 ダイマー間の有効相互作用パラメーターの值

\begin{tabular}{ccc}
\hline & 本研究での值 $(\mathrm{meV})$ & Ihm \\
\hline$V$ & -51.9 & -26 \\
$H$ & 6.6 & 10 \\
$D$ & 3.6 & 4 \\
\hline
\end{tabular}


法を使って求めた各構造間のエネルギー差から計算し た。その值を表 2 に示す。ことで計算した 4 種類の構造 の全エネルギー計算が，過去に Ihm ら ${ }^{13)}$ とって強束 縛近似を使ってなされている。彼らの計算では, 基底状 態は $p(2 \times 2)$ 構造である。彼らの計算によって求めら れた $V, H, D$ の值を表 2 に示す。ダイマーを形成する 二つの原子の間で, 固体に近い原子から真空側へ突き出 た原子へと電荷の移動が起こるので, ダイマーは, 表面 に平行な方向の電気双極子モーメントをむっている。彼 らの求めた值の比は, ダイマー間の相互作用が双極子相 互作用であると考えた場合の比とほぼ同じである。乙れ に比べてわれわれの計算で求めた值は，HとDの符号 と比については双極子相互作用に近いけれども，Vが双 極子相互作用の場合よりあはるかに大きい。これは，双 極子相互作用のほかに, 第 2 層の原子の間隔がダイマー の低いほうの原子のところではダィマー列方向に沿って 広がり, 高いほうの原子のところでは狭くなることによ って,ダイマー形成によって生じた歪エネルギーの損を 補うためであると考えられる。このような第 2 層の変位

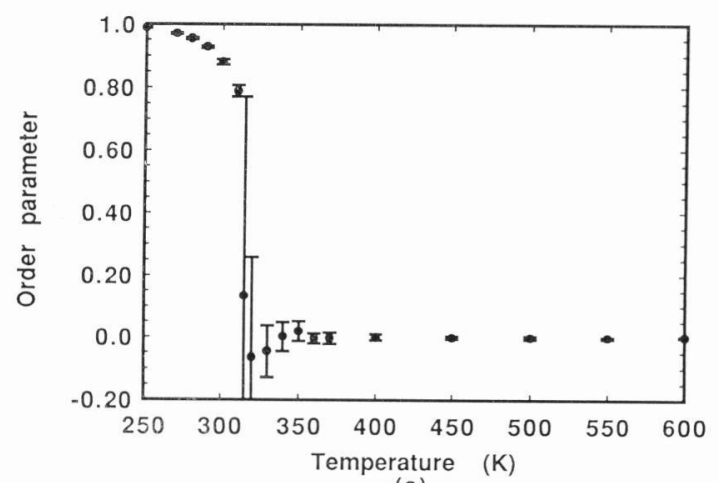

(a)

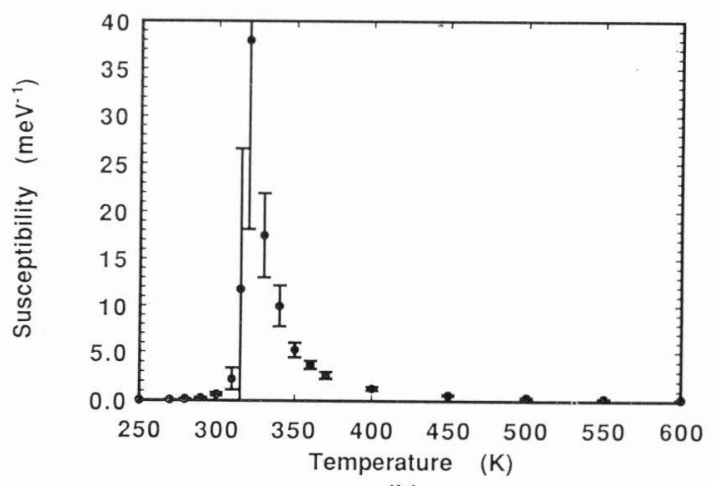

(b)

図 4 モンテカルロシミュレーションで計算された物 理量の温度変化
(a) 秩序パラメーター,
(b) 感受率

は, 対称性から $(2 \times 1)$ 構造と $(4 \times 1)$ 構造では起こら ず, $c(4 \times 2)$ 構造と $p(2 \times 2)$ 構造において可能である。 ゆえに，ダイマーを列に沿って交互に反対向きの配向で 並ばせる相互作用 $V$ が大きくなるのである。実際, 最適 化された $c(4 \times 2)$ 構造と $p(2 \times 2)$ 構造ではこのような 第 2 層の変位がみられる。

このようにして決められた(1)式のモデルハミルトニ アンを用いて, モンテカルロシミュレーションを行っ た。図 4 には秩序パラメーターとその感受率の温度変化 が示してある。秩序パラメーターは $c(4 \times 2)$ 構造になっ たときに 1 になるように定義してある。これらの值の変 化の様子加ら, $320 K$ で $c(4 \times 2)$ 相加ら無秩序相への 2 次の相転移が起こっていることがわかる。さらにこの表 面の低速電子回折の運動学的な強度の計算在行い, 実験 結果との比較を行った。図 5 に $300 \mathrm{~K}, 400 \mathrm{~K}, 600 \mathrm{~K}$ に おけるスペクトルを示す。 $300 \mathrm{~K}$ では, $c(4 \times 2)$ 構造の整 数次, 半整数次, $1 / 4$ 次のスポットが現れている。1/4次 スポットの周辺には, ダィマー列に垂直な方向に弱いス トリークが見える。転移温度よりも温度が高くなると， $1 / 4$ 次スポットの強度は急激に小さくなる。ストリーク は, 温度の上昇と共に強度が弱くなり幅も広くなるけれ ども，600K に拈いても依然として残っている。乙れ は, 高温においてもダイマー間のダィマー列方向の短距 離相関が，ダイマー列に垂直な方向へのそれに比へてて なり大きいまま残っているためである。Saxena ら ${ }^{14)}$ は, 同様のシミュレーションを $\mathrm{Ihm}$ らの求めたパラメータ 一を使って行っている。彼らのシミュレーションでは, $p(2 \times 2)$ 構造から無秩序相への転移が起こっているが, われわれの計算で見られたような短距離相関の非常に強 い異方性は見られないようである。村田ら ${ }^{9)}$ の低速電子 回折の測定においてもこのような弱いストリークが観測 されていて, $400 \mathrm{~K}$ ぐらいまではストリークを観測する

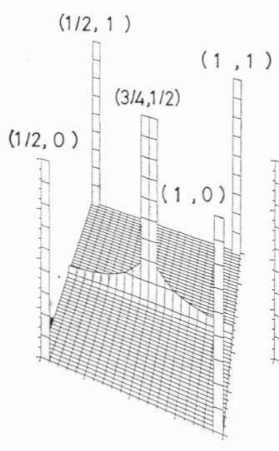

(a)



(b)

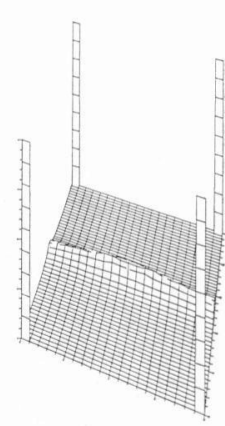

(c)
図 5 モンテカルロシミュレーションで計算された運 動学的な低速電子回折の構造

(a ) $300 \mathrm{~K}, \quad$ (b ) $400 \mathrm{~K}, \quad$ (c) $600 \mathrm{~K}$ 
ことが可能である。転移温度は実験よりは少し上になる が, 基底状態が $c(4 \times 2)$ で, 高温になると無秩序相に移 り,さらに転移温度よりあかなり高い温度においてもこ のようなストリークが残っており，てれは実験結果をよ く再現している。

現実の表面には数\%にも及ぶ火陥が存在しているよ うであり，1/4 次スポットの強度曲線の半值幅などの実 験と理論の比較には，乙の欠陥の効果を考慮する必要が ある。同様のことが STM 像の解釈についてもいえる であろう。欠陥の効果を取り入れたシミュレーションが 現在進行中である。

\section{4. $\mathrm{Si}(001)$ アルカリ金属吸着表面}

$\mathrm{Si}$ (001) 表面へのアルカリ金属吸着の最初のモデルは 1973 年に Levine $\mathrm{e}^{15)}$ にって提案された。Si(001) 面の
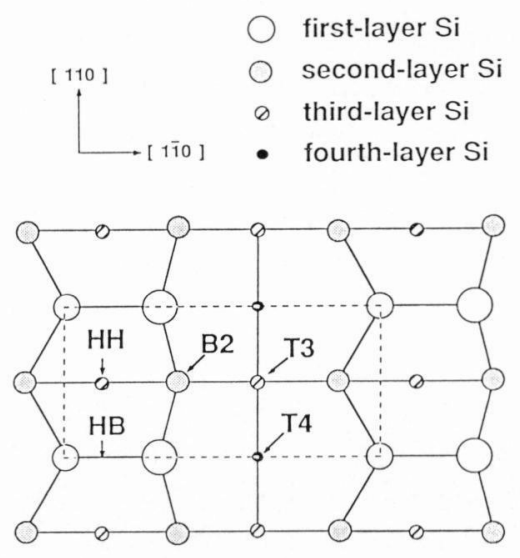

図 $6 \mathrm{Si}(001) 2 \times 1$ 非対称ダイマー構造

$\mathrm{HH}, \mathrm{HB}, \mathrm{B} 2, \mathrm{~T} 3, \mathrm{~T} 4$ の各吸着サイトを示す

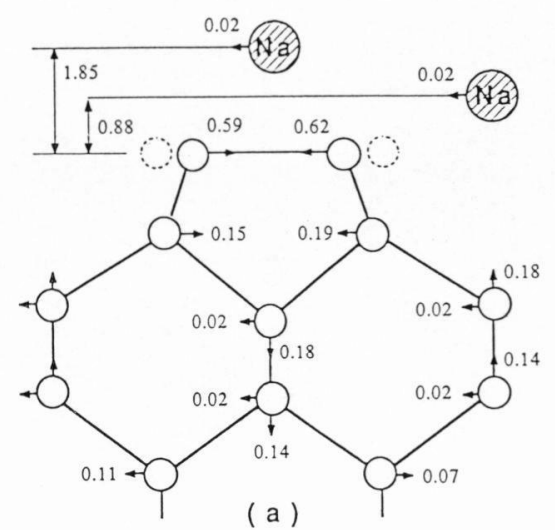

(a)
吸着サイトを図 6 亿示す。 $\mathrm{Si}(001)$ セシウム吸着表面を 酸素に露出すると, 仕事関数がさらに下がり, バルクの アフィニティレベルが真空レベルよりも高くなるという 現象 (Negative Electron Affinity) が起こることが実験 的に知られていた。この現象を説明するために Levine はつぎのような構造モデルを考えた。セシウム原子はダ イマー列上のホロウサイト ( $\mathrm{HH}$ サイト) に吸着し, や や正にイオン化することによって基板から真空側に向い た電気双極子を作り仕事関数を下げる。酸素は洞穴状に なったサイト（T４サイト）に吸着して負にイオン化し 仕事関数をさらに下げる。このモデルでは被覆率が 0.5 モノレイャーになり, ダィマー列に沿って 1 次元金属的 なセシウム原子鎖ができることが特徴的である。とこ ろで 1987 年に遠田 ${ }^{16)}$ は真空紫外光電子分光を用いて カリウム吸着 $\mathrm{Si}(001)$ 表面の電子状態について研究を行 った。その結果カリウム飽和吸着面はバンドギャップが 存在する半導体的な表面であることを見出した。このこ とは 1 次元金属的なアルカリ金属鎖をむつ Levine モデ ルと矛盾する結果であった。この結果に合致するモデル は1988 年虬川と河野 ${ }^{17)}$ にって提出された。彼らはX 線光電子回折による回折図形を運動学的に解析し, アル カリ原子はダイマー列上のサイトに加えてダイマー列間 のサイトにも吸着しているとする二段吸着モデルを提案 した。石田と寺倉 ${ }^{18)}$ とよる電子状態計算によって，二段 吸着モデルは半導体的な表面状態をもち, 光電子分光の 結果と一致することが示された。

虬川一河野の二段吸着モデルはいくつかの実験によっ て支持されている。そのなかでも最も印象深いものは田 中ら ${ }^{19)}$ にる昇温脱離分光の実験である。彼らの実験結 果によると, 脱離エネルギーの異なる 2 種類のピークが

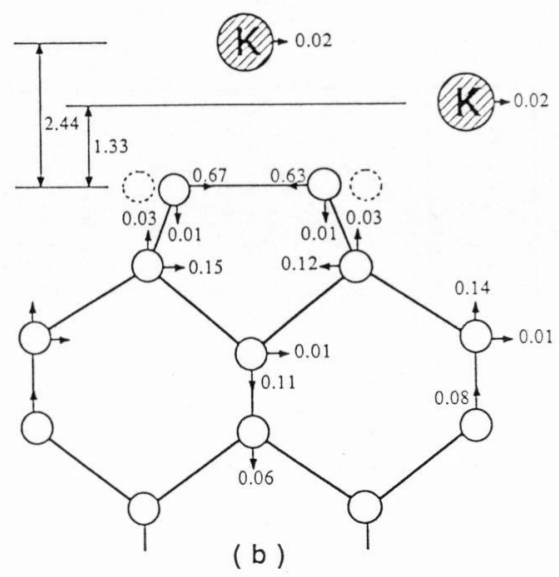

図 7 1.0モノレイヤー吸着したときの構造

( a ) ナトリウム，（b ) カリウム。基板のシリコン原子の位置は理想表面からのずれを $\AA$ 単位で示して ある。アルカリ原子の表面平行方向の位置は HH，または T 3 サイトからのずれで示してある 
存在し，それらのピークの面積強度はほぼ等しい。この ことは 2 種類の吸着状態にあるカリウム原子が等量存在 するととを示唆している。そのほかイオン散乱 ${ }^{20) や ~}$ $\mathrm{RHEED}^{21)}$ による実験は二段吸着モデルを支持している が, Glander と Webb ${ }^{22,23)}$ は低速電子回折とオージェ 電子分光を用いた研究により, 室温よりやや高い温度範 囲でナトリウムの飽和吸着量は 0.68 モノレイヤーであ ると結論している。てのように, まだ Levine モデルを 支持する研究結果屯報告されており, 決着がつけられて いなかった。

第一原理分子動力学法を用いていくつかの被覆率につ

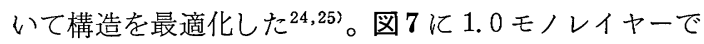
のナトリウムおよびカリウム吸着構造を示す。この構造 はX線光電子回折 ${ }^{17)}$ や低速電子回折の強度解析 ${ }^{26)}$ によっ て得られた構造とよく一致している。この構造がどの程 度安定であるか見るために，吸着エネルギーの被覆率依 存性を求めた。求めた吸着エネルギーを図にしたのが図 8 である。カリウム吸着については田中ら ${ }^{19)}$ の昇温脱離 分光により脱離エネルギーの被覆率依存性が実験的に求 められており，その結果を破線で示してある。実験と計 算結果がおおむね一致しているととがわかる。リチウ ム, ナトリウム, カリウムとあに 1.0 モノレイヤーまで は吸着エネルギーは $1.7 \sim 2.2 \mathrm{eV}$ と比較的大きく, 室 温で十分安定に吸着していると考えられる。1.0 モノレ イヤーを越えると, ナトリウム, カリウムの場合は吸着 エネルギーは $1.0 \mathrm{eV}$ 以下に急減する。乙の程度の吸着 エネルギーでは室温かそれよりあやや高い温度では安定 に吸着できず, 脱離してしまうであろう。実際, 昇温脱 離分光 ${ }^{19,27}$ によると, ナトリウムとカリウムは共に室温 よりやや高い温度でマルチレイヤーからの脱離が観測さ れ, さらに温度が高くなると第一層目からの脱離が観測 されている。乙のととから，ナトリウムとカリウムの場 合, 室温かそれよりやや高い温度での飽和吸着量は 1.0 モノレイヤーであると考えられる。一方, リチウムの場 合は吸着エネルギーが 1.0 モノレイヤーを越えても 1.7 $\mathrm{eV}$ 程度あり，乙れはリチウムの凝集エネルギーよりあ やや大きく, 室温付近での飽和吸着量は 1.0 モノレイヤ 一以上であると考えられる。また，リチウムが 2.0 モノ レイヤー吸着すると Si ダイマー結合が切れて, 基板は ほぼ $1 \times 1$ 構造をとる。乙のととは杤原, 村田ら ${ }^{28)} に よ$ る低速電子回折の $1 \times 1$ パターンと一致し, シリサイド 形成の初期過程であると考えられる。

カリウムの場合の吸着エネルギーは被覆率の増加とと あに減少していくが,ナトリウムの場合は 0.5 モノレイ ヤ一付近から增加している。このととから,ナトリウム がある被覆率以上になると一様に吸着するよりあ密に

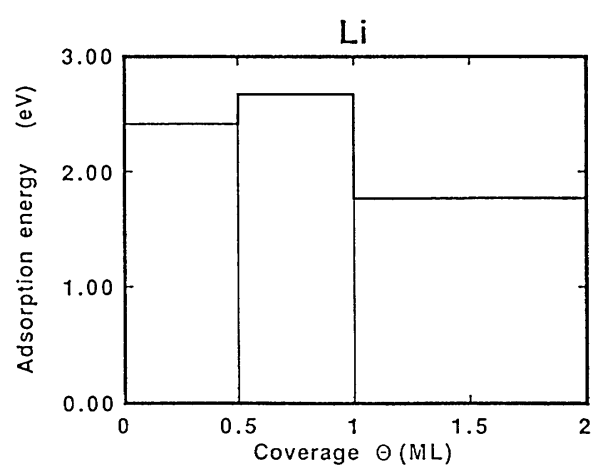

(a)

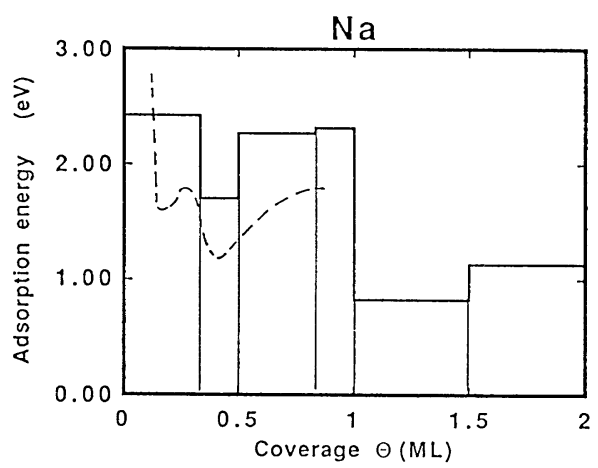

(b)

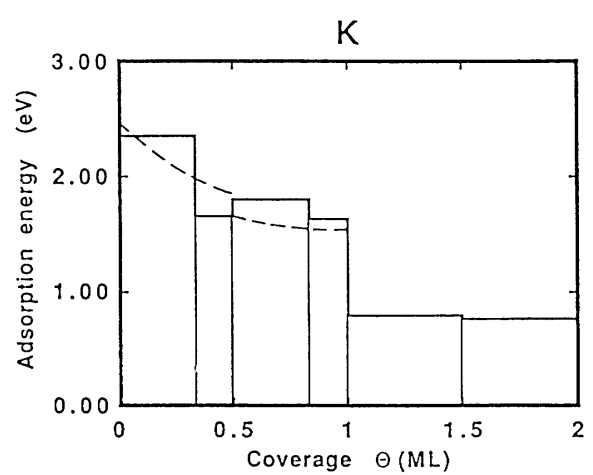

(c)

図 8 吸着エネルギー被覆率依存性

(a)リチウム吸着, (b ) ナトリウム吸着, (c)力 リウム吸着についてそれぞれ示してある。ナトリ ウム吸着については Glander と Webb到による 実験結果，カリウム吸着については田中ら ${ }^{19)}$ によ る実験結果を破線で示してある

吸着したパッチを形成したほうが安定であると考えられ る。このことはナトリウム吸着系の仕事関数の変化に表 われていると考えられる。Tikhov ${ }^{27) や ~ G l a n d e r 22,23) ~ ら ~}$ の実験によると,ナトリウムの被覆率が増加していくと 
ある被覆率のところで仕事関数が急激に減少する。さら にこの仕事関数が急激に減少する被覆率は温度とともに 高くなることも調べられている。これはある被覆率のと ころで島状の成長が始まり, smoluchowski 効果により

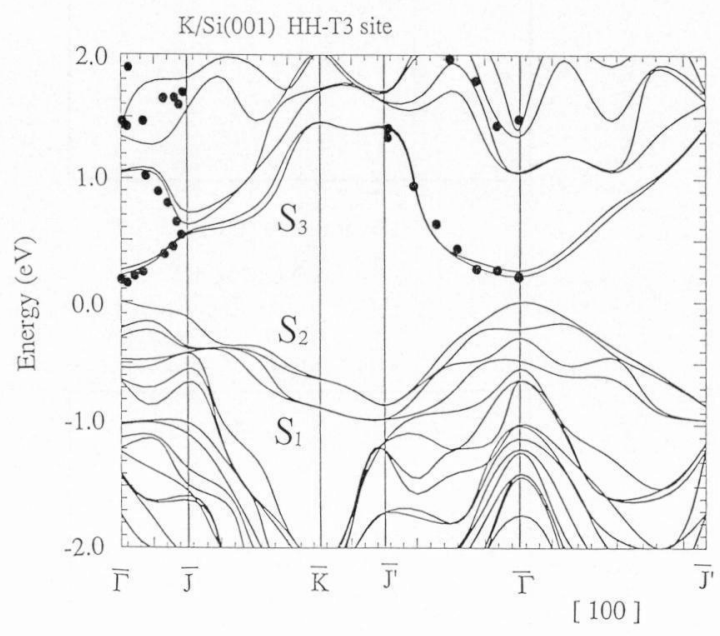

図 $9 \mathrm{Si}(001) 2 \times 1-\mathrm{K}$ 二段吸着モデルでのバンド構 造

エネルギーは占有状態の最も高いレベルを原点にと ってある。Johansson と Reihl による逆光電子分光 の結果を黒まるで示してある。ただし，実験結果と 計算結果が $\Gamma$ 点で一致するように実験結果を約 0.8 $\mathrm{eV}$ シフトさせてある
仕事関数が急減したと考えられる。カリウムではこのよ うな現象は見られず，ほぼ一様に吸着していくと考えら れる。

図 9 亿カリウムの 1.0 モノレイヤーでのバンド構造を 示す。カリウムおよびナトリウムの飽和吸着表面につい ては角度分解光電子分光 ${ }^{29)}$ 之角度分解逆光電子分光 ${ }^{301}$ に よって電子の占有状態执よび非占有状態についてバンド 構造が求められている。実線が計算によるバンド構造 で, 黒丸は逆光電子分光による結果である。実験と理論 の結果がたいへん良く一致していることがわかる。占有 状態についても Abukawa らの論文 ${ }^{29}$ 亿実験と理論計 算との比較が示されているが，一致はかなり良いととが わかる。ナトリウムについても実験と理論のよい対応が 得られている。

実験と理論の対応でさらに興味深い例はSTM 像で ある。Soukiassian ら ${ }^{31} の$ STM 像ではちょうど Levine モデルでのアルカリ原子の配列に対応すると思われ る像が見え， 2 段吸着モデルで予想される 2 種類のアル カリ原子は観測されなかった。しかしながら，STM 像 は原子の配列が直接見えるのではなく, それらが作る電 子状態を見ているので, 乙れを調べてみる必要がある。 この像を解析するためにフェルミレベル近傍の状態につ いて, 空間分布を調べた。ナトリウムとカリウムの場合 について図10亿示してある。この眓は表面に平行でア

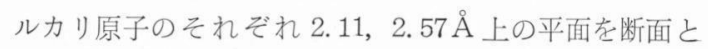



(b) $\mathrm{K} / \mathrm{Si}(\mathrm{O} 0 \mathrm{O} 1)$

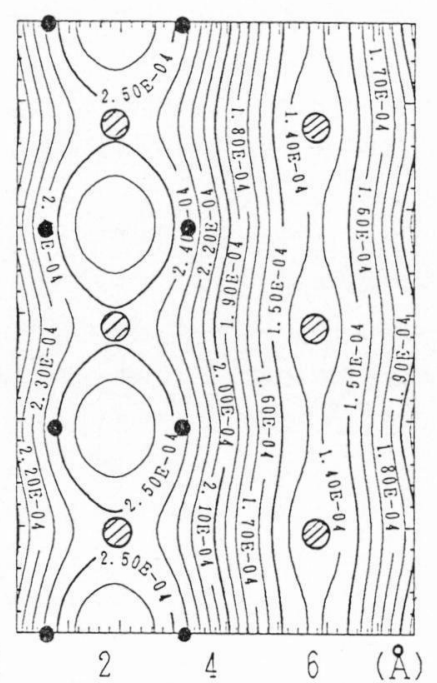

図 10 フェルミレベル付近の状態の空間分布

(a)ナトリウム吸着，(b)カリウム吸着。断面は表面に平行で，ナトリウ ム (カリウム) 原子の $2.11(2.57) \AA$ 上にある。第 1 層 Si 原子の位置は黒 まるで示してあり, アルカリ原子の位置は斜線入り白まるで示してある 
して書いてある。第 1 層 $\mathrm{Si}$ 原子の位置は黒まるで, アル カリ原子の位置は斜線入り白まるで示してある。フェル ミレベル付近の状態は, アルカリ金属の上でなくSiダィ マー上に主に分布している。このととから, STM 像で 明るく見えている部分はアルカリ金属に対応しているの ではなく, Siダイマーが見えているのであり, STM 像 も二段吸着モデルと一致するととがわかる。また最近, 甕ら ${ }^{32}$ によって $\mathrm{Na}$ 飽和吸着 $\mathrm{Si}(001)$ 表面の STM 像が 提出された。乙の像は分解能がよく, 図 10 (a) に示さ れているような括れた落花生形の像が観測されている。

\section{5.むすび}

以上で述べたように, 基底状態の構造や電子状態につ いては, 第一原理分子動力学法の結果は実験とよく対応 がつくことがわかる。 Si (001) 清浄表面の問題では, 第 一原理分子動力学法で求めた全エネルギーからモデルハ ミルトニアンのパラメータの大きさを導き出すことによ り，有限温度での状態についても非経験的な計算がかな り良く実験と対応することがわかった。また，アルカリ 金属吸着表面では，実験的に論争されていた問題に明確 な解答を与えるととができた。

今後の課題としてはつぎのようなものがあげられる。

（1）平面波基底による偽ポテンシャル法では取扱が 困難な遷移金属や酸素原子など, 比較的局在し た軌道をむつ元素む取り扱えるように偽ポテン シャルやアルゴリズムを改良する。

（2）より高速なアルゴリズムを開発して，より大き な系の取り扱いや，有限温度領域での原子運動 の追跡を可能にする。

（3）計算の基礎となっている局所密度近似の不十分 な点を一般化された密度勾配展開法などによっ て改善し,より定量的に信頼度の高い計算を行 う。また，局所密度近似では定性的にも不十分 であった磁性物質をあ扱えるようにする。

現在すでにいくつかの方法が試みられて拉り, 成果を あげつつある。これらの方法論の開発と高速計算機の進 歩によって, 構造だけでなく, 固体表面での原子分子の 吸着過程や反応などを精度よく予想することが可能にな るであろうと期待される。

\section{文献}

1) R. Car and M. Parrinello: Phys. Rev. Lett. 55, 2471 (1985).

2) Car-Parrinello 法の解説として, 小口多美夫, 佐々木泰造 : 固体物理 25, 857 (1990).

3) 寺倉清之, 浜田典昭: 固体物理 20,700 (1985).

4) 従来の密度汎関数法によるバンド計算法の解説 として, 寺倉清之, 浜田典昭: 固体物理 19, 448
(1984).

5) R. M. Tromp, R. J. Hamers and J. E. Demuth : Phys. Rev. Lett. 55, 1303 (1985).

6) J.A. Appelbaum, G. A. Baraff and D.R. Hammann: Phys. Rev. Lett. 35, 729 (1975).

7) F. J. Himpsel and D.E. Eastman: J. Vac. Sci. Technol. 16, 1297 (1979).

8) D. J. Chadi : Phys. Rev. Lett. 43, 43 (1979).

9) T. Tabata, T. Aruga and Y. Murata : Surf. Sci. 179, L 63 (1987).

10) R. A. Wolkow : Phys. Rev. Lett. 68, 2636 (1992).

11) Y. Enta, S. Suzuki, S. Kono and T. Sakamoto: J. Phys. Soc. Jpn. 59, 657 (1990).

12) Z. Zhu, N. Shima and M. Tsukada: Phys. Rev. B 40, 11868 (1989).

13) J. Ihm, D. H. Lee, J. D. Joannopoulos and J. J. Xiong: Phys. Rev. Lett. 51, 1872 (1983).

14) A. Saxena, E. T. Gawlinski and J. D. Gunton : Surf. Sci. 160, 618 (1985).

15) J. D. Levine: Surf. Sci. 34, 90 (1973).

16) Y. Enta, T. Kinoshita, S. Suzuki and S. Kono: Phys. Rev. B 36, 9801 (1987).

17) T. A bukawa and S. Kono: Phys. Rev. B 37, 9097 (1988).

18) H. Ishida and K. Terakura: Phys. Rev. B 40 , 11519 (1989).

19) S. Tanaka, N. Takagi, N. Minami and M. Nishijima : Phys. Rev. B 42, 1868 (1990).

20) A. J. Smith, W. R. Graham and E. W. Plummer : Surf. Sci. 243, L 37 (1991).

21) T. Makita, S. Kohmoto and A. Ichimiya : Surf. Sci. 242, 65 (1991).

22) G.S. Glander and M. B. Webb : Surf. Sci. 222, 64 (1989).

23) G. S. Glander and M. B. Webb : Surf. Sci. 224, 60 (1989).

24) Y. Morikawa, K. Kobayashi, K. Terakura and S. Blügel : Phys. Rev. B 44, 3459 (1991).

25) K. Kobayashi, Y. Morikawa, K. Terakura and S. Blügel : Phys. Rev. B 45, 3469 (1992).

26) C. M. Wei, H. Huang. S. Y. Tong, G. S. Glander and M. B. Webb : Phys. Rev. B 42, 11284 (1990).

27) M. Tikhov, G. Boishin and L. Surnev: Surf, Sci. 241, 103 (1991).

28) H. Tochihara and Y. Murata: Surf. Sci. 215 L 323 (1989).

29) T. A bukawa, T. Kashiwakura, T. Okane, Y. Sasaki, H. Takahashi, Y. Enta, S. Suzuki, S. Kono, S. Sato, T. Kinoshita, A. Kakizaki, T. Ishii, C. Y. Park, S. W. Yu, K. Sakamoto and T. Sakamoto: Surf. Sci. 261, 217 (1992).

30) L.S. O. Johansson and B. Reihl: Phys. Rev. Lett. 67, 2191 (1991).

31) J. A. Kubby, W. J. Greene and P. Soukiassian : J. Vac. Sci. Technol. B 9, 739 (1991).

32) 寉 久美, 橋詰富博, 陸 華, JEON DongRyul, 桜井利夫 : 日本物理学会第 47 回年会（慶 大日吉, 1992). 